\title{
Covid-19 and Collective Memory Among Malaysians: Does Generation Matter?
}

\author{
Hasrina Mustafa ${ }^{1}$, Sharifah Nadiah Syed Mukhiar', Shariffah Suraya Syed Jamaludin² \\ and Norhani Mohd Jais ${ }^{1 *}$ \\ ${ }^{1}$ School of Communication, Universiti Sains Malaysia, 11800 USM Penang, Pulau Pinang, Malaysia \\ ${ }^{2}$ School of Social Sciences, Universiti Sains Malaysia, 11800 USM Penang, Pulau Pinang, Malaysia
}

\begin{abstract}
The present study aims to understand the impact of Covid-19 on the collective memory among Malaysian generational cohorts. Our research draws on a nationwide survey conducted from July-September 2020 during the second pandemic wave in Malaysia. Respondents were asked to report "the national or world events or changes over the past 60 years" that seemed to them especially important and explain the reasons for their choices. As expected, the result indicated Covid-19 as the most frequently mentioned event. Despite the primacy and recency of the event, we found significant cohort effects on the collective memory of Covid-19, with lower recall recorded among the older generation as compared to the younger generation, which provided stronger support to the Critical Years Hypothesis. Interesting cohort experiences emerge in the meaning attached to Covid-19 across different generational cohorts through open-ended follow-up questions.
\end{abstract}

Keywords: Collective memory, Covid-19, Critical Years Hypothesis, generational cohort

ARTICLE INFO

Article history:

Received: 15 May 2021

Accepted: 12 September 2021

Published: 03 December 2021

DOI: https://doi.org/10.47836/pjssh.29.4.15

E-mail addresses:

hasrina@usm.my (Hasrina Mustafa)

nadiahmukhiar@usm.my (Sharifah Nadiah Syed Mukhiar)

shariffah@usm.my (Shariffah Suraya Syed Jamaludin)

norhani.mj@gmail.com (Norhani Mohd Jais)

* Corresponding author

\section{INTRODUCTION}

Dramatic and highly emotional historical events often left a significant imprint on generational memory. War, natural disasters, and many life-threatening events normally evoke traumatic and painful experiences. Hence, those would be more likely to be remembered collectively by a generation. World War II, for example, one of the world's biggest global conflicts, arouses the greatest fear and horror among 
the older generation. Likewise, tsunami, one of the world's most dramatic natural disasters, evokes a strong essence of major devastation and loss. So much so it remains strong and vivid in the memory of those who experienced this natural catastrophe.

In addition to war and natural disasters, epidemics and pandemics spread over many countries and regions often left momentous consequences and emotional impacts to specific generational cohorts. The Severe Acute Respiratory Syndrome (SARS) and Ebola, for example, may vary in their impact continuum according to respective affected regions. Consequently, they have different recollection effects on different generations. Similar to SARS and Ebola and many other epidemics faced by previous generations, the current generation is now battling Covid-19, the deadliest pandemic in world history. Will Covid-19 become part of collective memory among Malaysians? Do we now collectively recall the hassle of wearing a face mask, sanitizing our hands, and checking our body temperature at various public areas? Will our recall of the series of nationwide lockdowns and localized lockdowns remain vivid in memory? How do different generations of Malaysia remember Covid-19, and how salient is the memory across generations?

This paper is the first empirical paper that aims to understand the impact of Covid-19 on the collective memory of Malaysians. Our research draws on a nationwide survey conducted from JulySeptember 2020 to understand whether Covid-19 plays a role in the collective memory of different generational cohorts in
Malaysia. In addition, we critically explore reasons for indicating Covid-19 as the most momentous events of their lives through open-ended follow-up questions.

\section{Collective Memory and Critical Year Hypothesis}

Collective memory refers to "recollection of events shared by a group" (Roediger \& Abel, 2015, p. 359). According to Wertsch and Roediger III, "collective memory is a form of memory that transcends individuals and is shared by a group" (2008, p. 318). According to Schuman and Scott (1989), collective memory is a widely shared knowledge of past social events that may not have been personally experienced but are collectively experienced through communicative social function. In simple words, collective memory refers to how groups remember their past.

Collective memory shares several core elements. Firstly, it can be connected to a specific event (Schuman \& Corning, 2012), such as the Vietnam war, the Tsunami, or the Independence Day of Malaysia. Second, it can be a historical change that spans time, such as the social media revolution. Finally, some historic changes unique to Malaysians are the reformation movement led by Anwar Ibrahim, the former Deputy Prime Minister of Malaysia, spanning two decades from 1998 until 2018.

Secondly, collective memory varies by its intensity. The collective memory of an event may evoke different intensities across various generational cohorts. Schuman and Corning (2017) found strong collective 
memory of the September 11,2001, terrorist attack on the United States, especially among 11-30 years in 2001. Scott and Zac (1993), in a survey of British and American households, found striking similarities in collective historical memories between the two nations, with World War II recording the highest mention, especially among the older generation aged 50 years and above. However, the two nations differ in their interpretation and meaning attached to the same event. Interestingly the Americans associated WWII with prosperity and fortune gained after that. The detailed narratives and stories reflecting fear, tragedy and horror among the British remained dominant as the war occurred close to their homeland.

Central to the concept of collective memory is the Critical Years Hypothesis. The Critical Years Hypothesis posits that the shared memory of momentous events during the "coming of age" years would remain strong and relatively unchanged throughout life (Schewe \& Meredith, 2004). It is suggested that formative years generally begin at about age 17 and end by age 25 (Schewe \& Meredith, 2004), while Schuman and Rieger (1992) roughly identified 13-25 years as the formative years. The lower and the upper age boundary is rather arbitrary.

Despite some discrepancy on the formative years' lower and upper age boundary, it is generally believed that historical events occurring during the formative years would be vividly remembered as it is during the period, distinctive personal characteristics and personality of a person begin to emerge.
With social interaction during childhood limited to parents and immediate family members, historical events experienced during infancy and early childhood will not be remembered clearly. According to Griffin (2004), historical events occurring during formative years are most impactful because, during these periods, a person gains knowledge of social realities outside of their personal and private environment during childhood. Schuman and Scott (1989) further noted that people would be intellectually mature enough to understand the social, political, and economic realms surrounding them during adolescent and early adulthood. They would be fascinated and immersed with their first encounter with social or political events, hence reminiscing the experience during later life. According to Corning and Schuman (2015), national and world events that occur during the critical years should have a lasting impact on individuals because they are usually the first major national or world event experienced and serve as a baseline against which later events are compared.

Empirical supports to the "Critical Years Hypothesis" have been widely documented in many studies in Western countries (see Schuman \& Corning, 2012; Schuman \& Corning; 2017; Scott \& Zac, 1993; Schuman \& Scott, 1989). In Asia, for example, Lee and Chan (2018), several studies found that the Tiananmen incident and the transfer of sovereignty in 1997 were deeply rooted in their collective memory among Hong Kong people. However, the collective memory among Beijing youth born between 1984 and 1992 was evident in Constantin's (2013) 
study. The study found that the Beijing youth recalled the Olympic Games in 2008 and the Sichuan earthquake in the same year. Both events took place during their formative years. Budiawan (2017) discussed the collective memory, termed explicitly as popular memory of the "Konfrontasi Malaysia-Indonesian or Ganyang Malaysia" in Indonesia. The meanings attached to this event do not change significantly over the years as it is transmitted over generations through mostly historical textbooks and class discussions.

In Malaysia, empirical evidence of collective memory across generations is scarce and inconclusive. In most studies, evidence of collective memory was recorded among the older generation involving dramatic historical events such as the Japanese Occupation. For example, Blackburn (2009) and Tay (2015) found that the Japanese Occupation was collectively recalled as a traumatic period in the lives of people now over seventy years old in Malaysia and Singapore. Ting et al. (2017) also uncovered strong collective memory, especially about the Japanese Occupation amongst those born during the 1930s. On the other hand, the generational cohorts born from 1943-1961 recalled mostly on the communist insurgency, British colonization, and the formation of Malaysia as they struggled to secure or maintain good lives during the said era. The same study also found that Malaysian Generation Z tended to remember mostly social media and technological advancements. At the same time, Generation Y recalled mainly on introducing Goods and Service Tax (GST) introduced in 2015.

\section{Covid-19 and Collective Memory}

The outbreak of various diseases such as SARS in 2002, H1N1 in 2009, and Ebola in 2013 have caused enormous negative impact upon individuals and, to a certain extent, led to structural changes in the economic, social, and cultural landscape of the international community (Centre for Disease Control and Prevention, 2020). Compared to the previous outbreaks, the ongoing Covid-19 is the largest or perhaps the deadliest outbreak after the Spanish Flu of 1918, killing more than 50 million people worldwide (Douglas et al., 2019). As of March 7, 2021, Covid-19, earlier known as the Coronavirus, has affected more than 116 million people in more than 213 countries globally. Officially declared a global pandemic by the World Health Organisation (WHO) on March 11, 2020, the virus has killed more than two million people worldwide (WHO, 2020). The highest number of fatalities were recorded in the USA at 500,000, followed by Brazil at 263,000 and India at 158,000 as of March 7, 2021.

Three waves of the pandemic have been hit Malaysia. The first wave began when the pandemic was first detected on January 25, 2020, involving three tourists from China who came to Malaysia via Johor Bharu from Singapore. The first wave lasted from January 25 to February 16, 2020, with small numbers of cases. The second wave started on February 27, 2020, and lasted until September 30, 2020, in response to the 
rising trend of infections (Rampal \& Liew, 2021). On March 18, 2020, the Malaysian government enforced the Movement Control Order (MCO). It had led to a total closure of schools, universities, government offices, and private premises; a total ban of any mass gathering for any religious, social, or cultural purposes; and a complete restriction for all inbound and outbound travel. The partial lockdown was extended several times with greater relaxation of the restrictions following a gradual decrease in Malaysia's confirmed cases. The flat epidemical curve remained before the third wave began on September 8, 2020, and further rose in October 2020 until March 2021 due to the sudden surge of cases mainly due to a state's election campaigning and lobbying activities. Malaysia has recorded more than 310,000 infections, with 1159 deaths as of 7, March 2021.

Covid-19 is undoubtedly the most lifechanging event of the 21 st century. First detected in Wuhan, China, the virus spread rapidly across the continents resulting in major disruption to the global economic activities. The introduction of emergency lockdowns, partial lockdowns, international and inter-state travel restrictions, limitations imposed on public gatherings, and total closure of business, social, and education institutions in various countries have caused direct, indirect, and spill-over effects upon the world economy (Baldwin \& Di Mauro, 2020). The pandemic has also caused major social and cultural changes in almost every aspect of human life, leading to new norms such as social distancing, health practices and limitation of persons at public gatherings, and the uptrend in online activities. In addition, social media advancement has caused the greatest coverage of the pandemic worldwide.

Covid-19 provides a new testing ground for the concept of collective memory and the "Critical Years Hypothesis." It is very life-changing and impactful locally and internationally. It has brought about major structural changes in society. In Malaysia, the pandemic has led to a series of partial lockdowns, total closures of all business and social activities, and restrictions on travel. How do different generational cohorts in Malaysia remember the pandemic? To what extent, the "Critical Years Hypothesis" hold in the case of Covid-19? Will those at the formative years aged between 18-30 in 2020 mention Covid-19 more frequently than the older cohorts of Malaysians?

\section{METHOD}

\section{Research Design}

A quantitative research approach was adopted to investigate the extent of recall of historical events among the Malaysian population. A set of questionnaires was distributed through online platforms to targeted respondents from five regions in Malaysia. Thus, a link was created and shared with enumerators, mainly university students residing in the country's five regions. The survey was conducted during the recovery period of the pandemic from July-September 2020, which saw a relaxation of restrictions with the reopening of schools, institutes of higher learning, and local businesses. 


\section{Population and Sampling Procedure}

The total number of respondents required for the survey was calculated based on the total Malaysian population aged 18 and above. According to the Department of Statistics Malaysia, in 2020, the total Malaysian population was approximately 32.6 million, and $70 \%$ were aged $18-64$ years old. As for the group of 65 years old and above there are $7 \%$ of the total population. Using Yamane's (1967) sample size calculation, around 1500 respondents were selected and divided into twelve age groups.

A clustered sampling technique was used to identify suitable respondents. First the states were divided according to region, namely North, South, East, West, and East Malaysia, to ease the process of sampling. Then, a specific state was randomly selected within each region, and people living and working in the particular state were considered respondents. Since it is quite impossible to source respondents from every state in Malaysia, the present study deliberately sampled four states to represent each region in Malaysia, i.e., Selangor/ Kuala Lumpur for the central region, Penang for the northern region, Kelantan for the eastern region, Johor for the southern region and Sarawak for East Malaysia. Afterward, the purposive sampling method was used to recruit samples for each age cohort. Purposive sampling or judgment sampling is a non-probability sampling method in which participants are selected based on the researcher's judgment that they meet the requirements of the study (Hair et al., 2009). In this study, the most important requirement is the age cohort. There are generally twelve age cohorts in the study, namely 18-20 years old, 21-25 years old, 26-30 years old, 31-35 years old, 36-40 years old, 41-45 years old, 46-50 years old, 51-55 years old, 56-60 years old, 61-65 years old, 66-70 years old and 71+ years and above.

\section{Research Instrument}

The questionnaire was designed based on the research conducted by Schuman and Rodgers (2004) and Schuman and Corning (2017). First, the respondents were asked the following, "There have been a lot of national, world events and media/musical/ political/ technological changes over the past 70 years say, from about 1930 right up until today. What historical events/changes from the past that you remember the most?" Next, the respondents were asked to indicate two historic events in their lives and rate their recall further based on a 5-point Likert scale with 0 indicating not remember at all and five as vividly remember. Finally, following methods by Scott and Zac (1993), Schuman and Scott (1989), and Harold and Fong (2017), the questionnaire included an open-ended question that asked respondents the reason for their choices to qualitatively explore the different meanings that people have of the mentioned events.

\section{RESULTS}

Table 1 presents the demographic details involving 1526 respondents of this study based on twelve age groups. Females make up the majority of respondents. Most 
Table 1

Respondents demographic background

\begin{tabular}{|c|c|c|c|}
\hline Variable & Variable items & Frequency & Percent \\
\hline \multirow[t]{2}{*}{ Gender } & Male & 659 & 43.4 \\
\hline & Female & 860 & 56.6 \\
\hline \multirow[t]{12}{*}{ Age-group } & $18-20$ & 163 & 10.7 \\
\hline & $21-25$ & 203 & 13.3 \\
\hline & $26-30$ & 150 & 9.8 \\
\hline & $31-35$ & 144 & 9.4 \\
\hline & $36-40$ & 114 & 7.5 \\
\hline & $41-45$ & 136 & 8.9 \\
\hline & $46-50$ & 123 & 8.1 \\
\hline & $51-55$ & 115 & 7.5 \\
\hline & $56-60$ & 104 & 6.8 \\
\hline & $61-65$ & 86 & 5.6 \\
\hline & $66-70$ & 105 & 6.9 \\
\hline & $>71++$ & 83 & 5.4 \\
\hline \multirow[t]{8}{*}{ Education level } & None & 35 & 2.3 \\
\hline & Primary school & 116 & 7.6 \\
\hline & Secondary school & 477 & 31.4 \\
\hline & Diploma & 405 & 26.6 \\
\hline & Bachelor degree & 374 & 24.6 \\
\hline & Master degree & 75 & 4.9 \\
\hline & $\mathrm{PhD}$ & 19 & 1.2 \\
\hline & Others & 20 & 1.3 \\
\hline \multirow[t]{6}{*}{ Income } & $<\mathrm{RM} 1000$ & 493 & 42.4 \\
\hline & RM1100-RM2000 & 300 & 25.8 \\
\hline & RM2100-RM3000 & 166 & 14.3 \\
\hline & RM3100-RM4000 & 96 & 8.2 \\
\hline & RM4100-RM5000 & 46 & 4.0 \\
\hline & $>$ RM5100 & 63 & 5.4 \\
\hline
\end{tabular}

respondents were educated at diploma and bachelor degree levels and earned an average of less than RM2000 a month.

In drawing our inferences, we are guided by three analyses; 1) descriptive analysis and graphic presentations of recall of historical events by age, 2) logistic regression analyses using age and two other stratification variables, namely educational level and gender for purposes of control and comparison and 3) Thematic analysis of reasons for choosing Covid-19 as the most important historical event, which can help us see more clearly the different perspectives on the past that people have.

Firstly, Table 2 indicates the frequency for the most repeatedly mentioned events and changes in Malaysia. The descriptive analysis presented using tables and diagrams was used to show the trend between the 
age groups. Altogether there were 26 major historical events mentioned. From the list of 26 events mentioned, Covid-19 recorded the highest recall percentage by respondents for both the first and second mention by $40.7 \%$ and $29.6 \%$, respectively. Tsunami 2004 was also frequently mentioned, with $9.6 \%$ for the first mention and $8.9 \%$ for the second mention. The 14th General Election in 2018 was also in the top three mentioned events, with $8.3 \%$ for the first mention and $16.3 \%$ for the second mention.

The plotted graph in Figure 1 below further shows how each age group recalled each particular event. Furthermore, it can be seen that although a majority of

Table 2

Ten most frequently mentioned events and changes in Malaysia

\begin{tabular}{lcc}
\hline Historical events & Frequency & Percentage \\
\hline COVID 19 & 621 & 40.7 \\
Tsunami 2004 & 141 & 9.2 \\
Independence of Malaysia 1957 & 128 & 8.4 \\
Malaysia 14 ${ }^{\text {th }}$ General Election (2018) & 120 & 7.9 \\
Introduction of GST 2015 & 86 & 5.6 \\
13 May 1969 incident & 53 & 3.5 \\
Economic crisis 97/98 & 33 & 2.2 \\
The collapsed of Highland Tower 1993 & 29 & 1.9 \\
Sporting events (i.e. Thomas Cup) & 25 & 1.6 \\
P. Ramlee's music/film 1960an & 22 & 1.4 \\
Total & 1526 & 100.0 \\
\hline
\end{tabular}

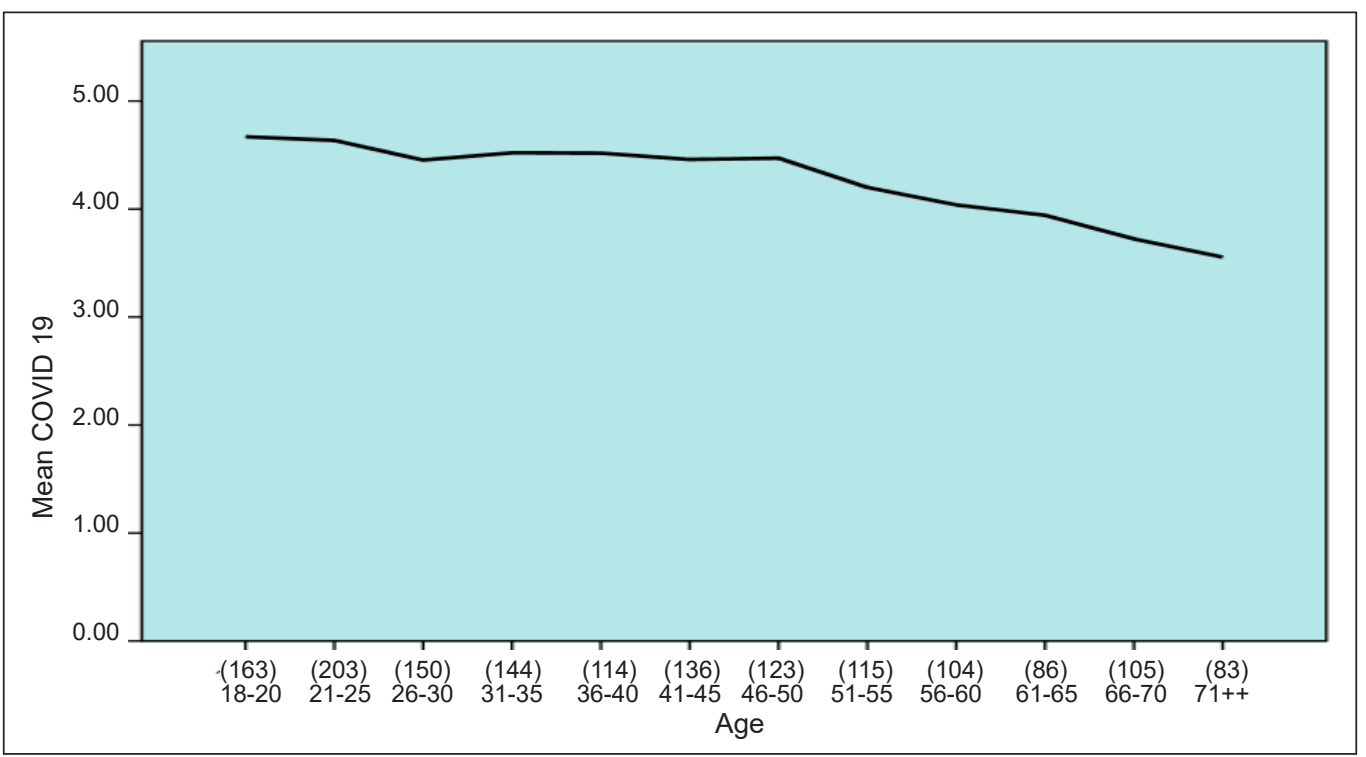

Figure 1. Mention of COVID19 
Malaysians mentioned COVID-19 as the most memorable event in their lifetime, the frequency differs across generations. It can be seen that the mentions of Covid-19 drop steadily with age. A substantial declining slope can be seen for respondents aged 46 years and above.

Table 3 shows the mean for mentions according to different age-range. As can be seen, more younger generations rated Covid-19 as the most memorable event for them than the older generations. The highest mean is 4.67 by those in the age range of 18 20 years old, while the lowest mean is 3.55 by those aged 71 years old and above despite the prevalence of the pandemic impacting every individual in the society.

Secondly, logistic regression was further conducted to test the effect of age, income, and education level on each historical event remembered. In Table 4, we show the results of a logit analysis on mentions of important events and changes by the level of education, age, and income. It can be seen that age is by far the strongest predictor of at least four historical events, namely Covid-19, the Independence of Malaysia in 1957, the historic $14^{\text {th }}$ General Election in 2018, and the sporting event (Thomas Cup 1992), while income has no significant impact on the recall of any historical events in Malaysia. On the other hand, the level of education is the best predictor for recall of the economic crisis in 1997. A strong cohort effect is discernible in the sample, especially in the context of Covid-19.

Thirdly, following recall of important historical events, the respondents were then asked to give the reason of their choice. Thus, in the analysis, our total $\mathrm{N}$ is reduced to 513 people who cited Covid-19 as the most important defining moment of their lives. Generally, we use an exploratory approach to thematic analysis in analyzing the data with no specific predetermined themes identified earlier (Guest

Distribution of mentions of COVID19 by age range

\begin{tabular}{cccc}
\hline Age group & Mean & $\mathrm{N}$ & Std. Deviation \\
\hline $18-20$ & 4.6687 & 163 & 0.72907 \\
$21-25$ & 4.6355 & 203 & 0.78672 \\
$26-30$ & 4.4533 & 150 & 0.77361 \\
$31-35$ & 4.5208 & 144 & 0.83598 \\
$36-40$ & 4.5175 & 114 & 0.85427 \\
$41-45$ & 4.4593 & 135 & 0.92044 \\
$46-50$ & 4.4711 & 121 & 0.78607 \\
$51-55$ & 4.2000 & 115 & 0.93846 \\
$56-60$ & 4.0385 & 104 & 0.94430 \\
$61-65$ & 3.9419 & 86 & 0.94998 \\
$66-70$ & 3.7238 & 105 & 1.24418 \\
$>71++$ & 3.5542 & 83 & 1.48368 \\
Total & 4.3381 & 1523 & 0.97500 \\
\hline
\end{tabular}


et al., 2019). However, we are guided by several themes derived from past studies on Covid-19 experiences, such as missing social contact, changes in daily life and lack of understanding of the preventive measures (Embregts et al., 2020), and perceived severity, especially among the elderly (Luo et al., 2021). Table 5 shows the percentage of responses for the observed main and sub-themes for mentioning Covid19 as the impactful historical event. Specifically, three sub-themes emerged across different age ranges: the overall changes due to the pandemic on lives and families, the economic impact, and the health impact of the pandemic.

Table 4

Logistic regression on the effect of education, income, and age to important events or changes in Malaysia

\begin{tabular}{lccc}
\hline & $\begin{array}{c}\text { Education } \\
\text { Odds ratio (OR) }\end{array}$ & $\begin{array}{c}\text { Age } \\
\text { Odds ratio (OR) }\end{array}$ & $\begin{array}{c}\text { Income } \\
\text { Odds ratio (OR) }\end{array}$ \\
\hline 1. COVID 19 & $\ldots$ & $0.76^{* * *}$ & $\ldots$ \\
2. Tsunami 2004 & $\ldots$ & $\ldots$ & $\ldots$ \\
3. Independence of Malaysia 1957 & $\ldots$ & $-1.18^{*}$ & $\ldots$ \\
4. $14^{\text {th }}$ General Election (2018) & $\ldots$ & $1.46^{*}$ & $\ldots$ \\
5. Introduction of GST 2015 & $\ldots$ & $\ldots$ & $\ldots$ \\
6.13 May 1969 incident & $\ldots$ & $\ldots$ & $\ldots$ \\
7. Economic crisis 97/98 & $-2.12^{* * *}$ & $\ldots$ & $\ldots$ \\
8. The collapse of Highland Tower 1993 & $\ldots$ & $\ldots$ & $\ldots$ \\
9. Sporting event i.e Thomas Cup) & $\ldots$ & $-2.62^{*}$ & $\ldots$ \\
11. P. Ramlee's music/film 1960an & $\ldots$ & $\ldots$ & $\ldots$ \\
\hline
\end{tabular}

Note. Based on logistic analysis of each event or changes using three predictors: education, income and age. The cell figures are statistically significant odds ratio (coefficient/standard error); ${ }^{*} p<.10 ; * * p<.05$; $* * * p<.01$

Table 5

Percentage of responses given by age-group for reasons for choosing Covid-19 as an impactful historical event

\begin{tabular}{llcccc}
\hline Main Theme & Sub-theme & \multicolumn{3}{c}{ Age categories (\%) } \\
\hline & & $\mathrm{N}$ & $18-30$ & $31-50$ & $51++$ \\
\hline Ongoing & Ongoing crisis & 123 & 8.8 & 3.6 & 4.6 \\
changes & New norm (social distancing etc) & 46 & 2.8 & 1.8 & 4.9 \\
& Changing life pattern & 27 & 3.1 & 1.6 & 1.6 \\
& Movement control order (MCO) & 53 & 3.7 & 3.3 & 4.3 \\
Health impact & Dangerous virus & 49 & 2.1 & 1.4 & 6.0 \\
& Deadly pandemic & 74 & 3.1 & 3.5 & 5.8 \\
& Increasing number of death & 42 & 1.6 & 1.6 & 6.9 \\
Economic & Losing job and source of income & 31 & 0.7 & 4.1 & 3.1 \\
& Effect on people's livelihood & 37 & 2.3 & 4.1 & 1.8 \\
& Economic crisis & 29 & 1.6 & 3.4 & 2.8 \\
\hline
\end{tabular}


Generally, for those between 18-30 years old, many mentioned Covid-19 to be most memorable as it is impacting their lives. However, many respondents have mentioned that this pandemic has huge implications for everyone. Lifestyle changes and adaptations to new norms are consistently mentioned. Below are some excerpts from respondents:

"because I am going through it. Covid-19 is the current case and I am 22 right now, so the impact is quite big in my life. Because our country is facing it right now."

"Because it is happening now and we don't know when it's going to end. Besides, it brings a great impact to whole world."

One respondent mentioned that COVID-19 is the most memorable as it happens while he/she is within her/his critical years by saying, "because it is happening while I am growing up."

Those from the 30-50 age group show another pattern. Their focus and importance are more directed towards financial issues due to the closure of business and loss of the source of income. They also have to overcome many obstacles while thinking of their family's livelihood. Changes have to be made in their lifestyle to adjust to the financial hardships caused by the pandemic. Below are some quotes by the respondents:

"My family was affected so much by Covid-19. We are being tested with various circumstances. It's affected the financial stability of people and their families."

"It changed the way my family and myself living our lives financially. It changed the whole routine of my life, my family and even the world."

The respondents from this age range also frequently mentioned the financial impact of the pandemic on their businesses. Business owners and freelancers are especially impacted. Below are some of the excerpts from the respondents:

"Covid-19 affected the sales in my clothing shop. "It gives economic impact, especially to business owners like me. My husband lost his source of income for months."

As for those who are 50 and above, many stated that they chose Covid-19 as the most memorable event because of the danger it poses to their health. Many realized that the disease could be fatal to them due to age and health conditions. Some mentioned that they are stressed and afraid of the current situation. Below are quotes from respondents aged 50 years and above:

"I am worried because it is dangerous and deadly. "I'm afraid of this situation right now. The virus is spreading everywhere. I am 62 years old."

"Covid-19 is dangerous to diabetic patients like me. I am worried for my health. The older generation should avoid any social gathering." 


\section{DISCUSSION}

How do different generational cohorts in Malaysia remember the pandemic? To what extent, the "Critical Years Hypothesis" hold in the case of Covid-19? Will young adults mention Covid-19 more frequently than the older generations?

Overall, the findings provide stronger empirical evidence on the role of dramatic historical events in constructing collective memory among Malaysians. Due to its intensity and enormous impact, Covid-19 was collectively recalled and remembered by most Malaysian adults. It could be due to its recency effect as the data collection was conducted in the second wave of the pandemic in Malaysia. Many Malaysians were still grappling with the pandemic. The recency effect has been evident in various other studies. For example, Roediger and DeSoto (2014) found higher recall of recent Presidents of America, and this memory declined linearly over time. The primacy effect would have been driven higher recall of Covid-19. With the pandemic directly impacting every individual at different agegroup and socio-economic statuses, the consistent recall of this major health crisis is highly predictable. A study by Schuman and Corning (2012) in three US surveys from 2001-2010 recorded empirical evidence on the primacy effect of the September 11 incident during the critical years of the respondents. According to Schuman and Corning (2013), personal experience of a major historical event would create a longlasting memory, compared to those gained via media or through narrations from others.
However, despite its widespread memory of the event, lesser recalls were evident from the older generations aged 46 and above. The present study's findings further provide more conclusive evidence on the theoretical importance of pre-adulthood experience with major historical events. The nomination of Covid-19 was found to be higher among the young adults (aged from 18-50 years) who are generally at their formative years compared to the older generations.

However, we found the recall of Covid-19 in the present study is noticeably wider, namely from those between 18-46 years old. With the pandemic still running rampant, the recall of the event could be readily available in the memory across different generational cohorts. Intense media coverage with daily case updates in the traditional media and live news streaming and breaking news in the digital media would contribute to this effect. With the event still unfolding, it may be too early to speculate on the precise age range for the critical period. A follow-up retrospective study thus is necessary to authenticate this further. We have two speculations here. The first speculation could be that this large cohort found in the present study will break into at least two when those who are now 18-25 will show a stronger recall in the future than the rest of the group due to the critical period effect. The second speculation is the much wider age range for the critical period impacted by Covid-19. According to Schuman and Corning (2012), the arbitrary range of the critical years could be wider or 
start at a much younger age due to repeated media coverage and intense discussion at school and among peers. The lower and the upper end of the critical period may vary depending on the nature of events. In the case of Covid-19, the age range could be wider due to the recency and primacy of the incident.

This age range is generally wider than those found in previous studies, ranging from 17-25 (Mannheim, 1952) and 12-29 (Schuman \& Rodgers, 2004).

Results of the Logistic Regression clearly showed the significant effect of the generational cohort in the recall of Covid-19. Furthermore, the same analysis also supported the significant effect of the generational cohort in most of the historical events mentioned, namely the Independence of Malaysia in 1957, the $14^{\text {th }}$ General Election in 2018, and various sporting events such as the Thomas Cup and Commonwealth Games, a which each generational cohort was found to exhibit higher recall of significant historical events during their formative years.

It is also striking to note that different meanings were attached to Covid-19, with young adults reflecting on the impact of the pandemic on their lifestyles and livelihood while the older generation, who are currently in their 50s, recounting their worries on health implications. Not every reason given by the respondents fits this conclusion precisely It may be quite premature to conclude the age structuring on meanings attached to Covid-19 as the pandemic is still unfolding. However, the findings from the present study may share a significant insight on the different meanings attached to Covid-19 across generational cohorts with higher perceived severity on health was recorded among the older generation. According to Chirwa (1997), collective memory would undergo a process of deconstruction and reconstruction over time due to the influence of various factors such as social group influence. Furthermore, according to Weldon (2000), recalling and interpretation historical events are socially constructed. Therefore, a person's memory and interpretation of a specific historical event would depend on one's mental engagement with his or her social group at a particular point in time. Frequent conversation and interaction within the same social group of the same generational cohort would influence the meanings attached to the pandemic, as observed in the present study.

No doubt, Covid-19 will create a longlasting impact on our collective memory compared to other pandemics and other historical events. With every development of the pandemic story mentioned by the mass media through conventional and digital channels, the impact of the pandemic will create a lasting impact on the creation of global memory as a whole (Erll, 2020).

\section{CONCLUSION}

Overall, the result of the present study has provided important support for the Critical Years Hypothesis. As expected, the mention of Covid-19 decreases with age, with a poorer recall of Covid-19 pandemic crisis 
among those aged 46 and above despite the recency and primacy of the event. Furthermore, based on Logistic Regression analysis, the present study provided stronger empirical evidence on the cohort effect on constructing a collective memory of major events in Malaysia, including Covid-19.

The study is significant as it examines the collective memory of a significant global event while the event unfolds. Previous studies on collective memory have been carried out in retrospect at the end of the event from a distant point in time. Studies on the collective memory of ongoing events are severely lacking except for a few studies by Twyman et al. (2017), who explored collaboration and collective memory of Black Lives Matter in Wikipedia. Results indicated intensified documentation, dynamic re-appraisal, and content curation on BLM in Wikipedia over time, reflecting the important role of "Wikipedia as a depository of collective memory" using revision history and pageview data (Luyt, 2015, p. 1956). Ferron and Massa (2011) explored the collective memory formation concerning the Egyptian revolution in 2011 in Wikipedia as the event unfolded. Results indicated progressive construction and reconstruction of collective memory with many contributions and editing participation on the English, Arabic, German, and Egyptian-Arabic Wikipedia websites. Kosciejew highlighted the importance of capturing the collective memory on Covid-19 as it occurs in real-time to ensure that "we can look to these contemporary (and eventually these past) experiences to move forward in any possible future global health crisis" (2021, p. 1). Theoretically, the present study offers stronger empirical evidence on the connection between collective memory and the Critical Year Hypothesis during an ongoing global pandemic.

Despite valuable findings, it is also important to also address some limitations of the present study. Firstly, the study was conducted during the second wave of the pandemic in Malaysia. Therefore, the high recall of the pandemic could be because the pandemic was still prevalent in the country. Furthermore, the present study provides significant insights into how people collectively remember Covid-19 while the pandemic is still ongoing and impacting every single individual worldwide. The high mention of the ongoing pandemic, especially among the younger people and lower among the older generations, further provides more empirical support for the "Critical Years Hypothesis." The findings tell us more about how the critical yearseffects is formed and how it developed, especially among those in their formative years as they carry on with their lives through the pandemic. Future studies could be conducted to measure the cohort effect on the intensity of the collective memory on Covid-19 over time.

Secondly, the study sample aged 75 and above, except for the younger generation, was limited. It is due to the difficulties in accessing them due to restricted mobility during the partial lockdown period and the challenges in managing the survey session with them, largely due to their limited physical capabilities and health conditions. 
Notwithstanding these limitations, the present study offers interesting findings on the impact of major defining global crisis on the collective memory of various generational cohorts of Malaysia. Confirming the age effect on the collective memory of Covid-19, the study further unearthed different narratives on Covid-19 recorded across different age groups.

\section{ACKNOWLEDGEMENT}

This work was supported by Universiti Sains Malaysia, Research University Individual (RUI) Grant Scheme with Project No: 1001/ PCOMM/8016046, Project Code: UO1778 (Reference No: 2019/0051).

\section{REFERENCES}

Baldwin, R., \& Di Mauro, B. W. (2020). Economics in the time of Covid-19. A CEPR Press VoxEU. org eBook. CEPR Press. https://cepr.org/sites/ default/files/news/COVID-19.pdf

Blackburn, K. (2009). Recalling war trauma of the Pacific War and the Japanese occupation in the oral history of Malaysia and Singapore. The Oral History Review, 36(2), 231-252. https://doi. org/10.1093/ohr/ohp041

Budiawan (2017). How do Indonesians remember Konfrontasi? Indonesia-Malaysia relations and the popular memory of "Confrontation" after the fall of Suharto. Inter-Asia Cultural Studies, 18(3), 364-375. https://doi.org/10.1080/146493 73.2017 .1345349

Centre for Disease Control and Prevention. (2020). Global disease detection timeline. www.cdc. gov/globalhealth/infographics/global-healthsecurity/global-disease-detection-timeline.html

Chirwa, W. (1997). Collective memory and the process of reconciliation and reconstruction.
Development in Practice, 7(4), 479-482. https:// doi.org/10.1080/09614529754314

Constantin, S. V. (2013). The post-80s generation in Beijing: Collective memory and generational identity. International Journal of Area Studies, 8(1), 5-36.

Corning, A., \& Schuman, H. (2015). Generations and collective memory. University of Chicago Press. https://doi.org/10.7208/ chicago/9780226282831.001.0001

Department of Statistics Malaysia. (2020). Pockets Stats Quarter 4 2020. https://www.dosm.gov.my/ v1/index.php?r=column/cone\&menu_id=YlUvc kptWm10Q1Q5Y0ZRdkErbG53dz09

Douglas, J., Terrence, T., \& Barbara, J. (2019, December 17). The deadliest flu: The complete story of the discovery and reconstruction of the 1918 Pandemic Virus. Centre for Disease Control and Prevention. https://www.cdc.gov/ flu/pandemic-resources/reconstruction-1918virus.html

Embregts, P. J. C., van den Bogaard, K. J. H. M., Frielink, N., Voermans, M. A. C., Thalen, M., \& Jahoda, A. (2020). A thematic analysis into the experiences of people with a mild intellectual disability during the COVID-19 lockdown period. International Journal of Developmental Disabilities. https://doi.org/10.1080/20473869. 2020.1827214

Erll, A. (2020). Afterword: Memory worlds in times of Corona. Memory Studies, 13(5), 861-874. https:// doi.org/10.1177/1750698020943014

Ferron, M., \& Massa, P. (2011). The Arab Spring wikirevolutions: Wikipedia as a lens for studying the real-time formation of collective memories of revolutions. International Journal of Communication, 5, 1313-1332.

Griffin, L. (2004). Generations and collective memory revisited: Race, region, and memory of civil rights. American Sociological Review, 69(4), 544-557. https://doi.org/10.1177/000312240406900404 
Guest, G., MacQueen, K. M., \& Namey, E. E. (2019). Introduction to applied thematic analysis. SAGE.

Hair, J. F., Bush, R. P., \& Ortinau, D. J. (2009). Marketing research: In a Digital information environment (4th ed.). McGraw-Hill/ Irwin.

Harold, J., \& Fong, F. (2017). Mobilizing memory: collective memory schemas and the social boundaries of Jews in Toronto. Ethnic and Racial Studies, 41(2), 343-361. https://doi.org/10.1080/ 01419870.2017 .1344719

Kosciejew, M. (2021). Remembering COVID-19; or, a duty to document the coronavirus pandemic. IFLA Journal. https://doi. org/10.1177/03400352211023786

Lee, F. L. F., \& Chan, J. M. (2018). Memory mobilization, generational differences and communication effects on collective memory about Tiananmen in Hong Kong. Asian Journal of Communication, 28(4), 397-415. https://doi. org/10.1080/01292986.2018.1425465

Luo, Y., Cheng, Y., \& Sui, M. (2021). The moderating effects of perceived severity on the generational gap in preventive behaviors during the COVID-19 pandemic in the U.S. International Journal of Environmental Research in Public Health, 18. https://doi.org/10.3390/ijerph18042011

Luyt, B. (2015). Wikipedia, collective memory, and the Vietnam War. Journal of the Association for Information Science and Technology, 67. https:// doi.org/10.1002/asi.23518

Mannheim, K. (1952). The problem of generations. In P. Kecskemeti (Ed.), Essays on the Sociology of Knowledge (pp. 276-320). Routledge and Kegan Paul.

Rampal L., \& Liew, B. S. (2021). Malaysia's third COVID-19 wave - a paradigm shift required. The Medical Journal of Malaysia, 76(1), 1-4.

Roediger, H. L., \& Abel, M. (2015). Collective memory: A new arena of cognitive study. Trends in Cognitive Sciences, 19(7), 359-361, https:// doi.org/10.1016/j.tics.2015.04.003

Roediger, H. L., \& DeSoto, K. A. (2014). Forgetting the presidents. Science, 346(6213), 11061109. https://doi.org/10.1126/science. 1259627

Schewe, C. D., \& Meredith, G. (2004). Segmenting global markets by generational cohorts: Determining motivations by age. Journal of Consumer Behaviour, 4(1), 51-63. https://doi. org/10.1002/cb.157

Schuman H., \& Rieger, C. (1992). Collective memory and collective memories. In M. A. Conway, D. C. Rubin, H. Spinnler, W. A. Wagenaar (Eds.), Theoretical perspectives on autobiographical memory. NATO ASI Series (Series D: Behavioural and Social Sciences), vol 65. Springer, Dordrecht. https:// doi.org/10.1007/978-94-015-7967-4_19

Schuman, H., \& Corning, A (2017). The conversion of generational effects into collective memories. International Journal of Public Opinion Research, 29(3), 520-532. https://doi. org/10.1093/ijpor/edw012

Schuman, H., \& Corning, A. (2012). Generational memory and the critical period: Evidence for national and world events. Public Opinion Quarterly, 76(1), 1-31, https://doi.org/10.1093/ poq/nfr037

Schuman, H., \& Corning, A. (2013). Collective memory and autobiographical memory: Similar but not the same. Memory Studies, 7(2), 146-160. https://doi.org/10.1177\%2F1750698013508196

Schuman, H., \& Rodgers, W. L. (2004). Cohorts, chronology, and collective memories. Public Opinion Quarterly, 68(2), 217-254. https:/doi. org $/ 10.1093 / \mathrm{poq} / \mathrm{nfh} 012$

Schuman, H., \& Scott, J. (1989). Generations and collective memories. American Sociological Review, 54, 359-381. https://doi. org/10.2307/2095611 
Scott, J., \& Zac, L. (1993). Collective memory in Britain and the United States. Public Opinion Quarterly, 57(3), 315-331. https://doi. org/10.1086/269378

Tay, F. (2015) Making Malaysian Chinese: War, memory, histories and identities [Doctoral dissertation, University of Manchester]. https://www.research.manchester.ac.uk/portal/ files/54574221/FULL_TEXT.PDF

Ting, H., Lim, T.-Y., Run, E. C., Koh, H., \& Sahdan, M. (2017). Are we baby boomers, gen $X$ and gen Y? A qualitative inquiry into generation cohorts in Malaysia. Kasetsart Journal of Social Sciences, 39(1), 109-115. https://doi. org/10.1016/j.kjss.2017.06.004

Twyman, M., Keegan, B. C., \& Shaw, A. (2017). Black lives matter in Wikipedia: Collaboration and collective memory around online social movements [ACM Press the 2017 ACM Conference - Portland, Oregon, USA (2017.02.25-2017.03.01)] Proceedings of the
2017 ACM Conference on Computer Supported Cooperative Work and Social Computing - CSCW '17 - Black Lives Matter in Wikipedia, 14001412. https://doi.org/10.1145/2998181.2998232

Weldon, M. S. (2000). Remembering as a social process. Psychology of Learning and Motivation, 40, 67-120. https://doi.org/10.1016/S00797421(00)80018-3

Wertsch, J. V., \& Roediger III, H. L. (2008): Collective memory: Conceptual foundations and theoretical approaches. Memory, 16(3), 318-326. http://doi. org/10.1080/09658210701801434

World Health Organization. (2020). WHO DirectorGeneral's opening remarks at the media briefing on COVID-19. https:/www.who.int/directorgeneral/speeches/detail/who-director-generals-opening-remarks-at-the-media-briefing-oncovid-19---11-march-2020

Yamane, T. (1967). Statistics, an introductory analysis (2nd ed.). Harper and Row. 
